\title{
FILIAL PIETY IN ISLAM AND CONFUCIANISM [A COMPARATIVE STUDY BETWEEN AHADITH AND THE ANALECTS]
}

\author{
M. Ikhsan Tanggok \\ Syarif Hidayatullah State Islamic University (UIN) Jakarta \\ ikhsan.tanggok@uinjkt.ac.id
}

\begin{abstract}
This paper concerns the issue of respect for one's parents in the context of Islamic and Confucian teachings. It is a comparative study between the teachings of these two traditions about this topic. In Islam, the concept of respect for one's parents is derived from the Quran and the ahadith of the Prophet Muhammad [S.A.W]. In Confucianism, the basis of the notion of respect for one's parents is taken from the Analects [Lunyu]. The Quran emphasizes the importance of honoring one's parents, while the ahadith of the Prophet Muhammad stress the importance of respecting one's mother to a greater degree than one's father. The message of the Lunyu resembles that of the Quran in focusing on respect for both parents and not only for one's mother. Confucianism is one of the official religions in Indonesia in addition to the other five [Islam, Catholicism, Christianity, Hinduism, and Buddhism].
\end{abstract}

Keywords: Filial Piety, Islam, Confucianism, Ahadith, Analects.

\section{Introduction}

Filial piety is an ethical concept and teaching that exists in all major world religions, such as Islam, Catholicism, Christianity, Hinduism, Buddhism, and Confucianism. Yet this concept has garnered special attention from two religions, namely Islam and Confucianism [Tanggok, 2000: 16]. In the former, the importance of honoring one's parents is not only explained in the Quran but also in the ahādith of the Prophet Muhammad. Filial piety is an obligation and not merely the optional Sunnah [tradition] of the Prophet Muhammad [S.A.W]. Because it is a duty for every Muslim, those who do not fulfill its requirements are considered to commit sin. Meanwhile, in Confucianism respect for one's parents is also very important. Filial piety for Confucians is not limited to when their parents are alive, but continues when they have died. This paper would like to consider whether there are differences and similarities between Islamic and Confucian notions of filial piety. However, only the ahādīth and Analects will be compared with respect to this issue. A hermeneutic method, namely one in which the interpretation of the meaning of the passages in question are studied [Mulyono, 2012:70], is employed here to fulfill the paper's goal.

\section{Filial Piety in Islam}

In the Quran, Allah commands human beings to practice filial piety and to honor their parents. Allah dispatches His orders concerning it in 17:23-24 of the Quran. In verse 23 of this chapter Allah says the following:

And the Lord hath decreed that ye worship none but Him, and that ye be kind to parents. Whether one or both of them attain old age [while] thy life, Say not to them [so much as], "uff," But address them in terms of honour. [Al-Isra: 23] 
In another verse Allah also explains:

"And, out of kindness, lower to them the wing of humility, and say: "My Lord!

Bestow on them thy Mercy even as they Cherished me in childhood." [Al-Isra: 24]

In other verses Lord also explains:

And serve Lord, and join not any partners with Him; and do good-to parents, ... [AnNisa : 36$]$

And also Lord explains in the chapter of Luqman verse 14-15.

And We have enjoined upon man [care] for his parents. His mother carried him, [increasing her] in weakness upon weakness, and his weaning is in two years. Be grateful to Me and to your parents; to Me is the [final] destination. [Luqman: 14].

This verse of the Quran explains that it is important to respect one's parents because they have given birth and raised their children. In verse 24 of the same chapter, human beings are asked not to refute parental commands and to humble themselves. The action of humbling oneself can be interpreted as honoring or respecting one's parents. In 31:14 of the Quran, Allah explains that one's respect for God must also be accompanied by respect for one's parents. Human beings are thus not only asked to honor God, but also to respect their parents.

Besides in the verses of the Qur'an above, the command to honor the parents could also be seen in the hadith of Muhammad as follows:

Abu Huraira reported: A man asked the Messenger of Allah, peace and blessings be upon him, "Who is most deserving of my good company?" The Prophet said, "Your mother." The man asked, "Then who?" The Prophet said "Your mother." The man asked again, "Then who?" The Prophet said, "Your mother." The man asked again, "Then who?" The Prophet said, "Your father." [Source: Șahīh al-Bukhārī 5626, Șahīh Muslim 2548].

Imam Al-Qurtubi explains, "The above hadīth shows that love and affection for a mother must be three times bigger than love or affection to a father. The Prophet [S.A.W.] mentions the word "mother" three times in the hadith above, while the word "father" is only uttered once and it is the fourth response. This means that while we love our mother three times, loving our father once is enough. It could also mean that our love for our mother must be more than our love for father. The reason for this is perhaps that a mother's responsibility in pregnancy, childbearing and rearing children is heavier than a father's duties. A mother carries her child for nine months and ten days in her stomach; wherever she goes, she carries the child with her. A mother is in charge of giving birth to her child which itself can put her life at risk. There are mothers who survive during childbirth while there are others who do not. This is one aspect which makes a mother's task very heavy, while the father only has a duty to earn a living for the benefit of him and his family [al-Qurthubi XIV: 65].This is probably why the Prophet Muhammad ordered his followers to honor and respect their mothers three times while their fathers only once. It is possible that the person who came to the Prophet Muhammad to ask whom he should respect is one who has committed many sins toward his mother.

A mother's rights over us are so great that the Prophet Muhammad once told a man not to join a military expedition so he could return to his parents and serve them, specifically his mother, for Paradise is under her feet.

Abdullah ibn Amr reported: A man came to the Messenger of Allah, peace and blessings be upon him, asking permission to strive in jihad. The Prophet said: Are 
your parents alive? He said yes. The Prophet said: Then strive in their service. [Sahih Bukhari 2842, Grade: Muttafaqun Alayhi]. In another narration, the Prophet of Muhammad said: Then return to your parents and treat them with good company. [Sahih Muslim 2549, Grade: Sahih]

Mu'awiyah ibn Jahima reported: A man came to the Messenger of Allah [Muhammad], peace and blessings be upon him, and he said, "O Messenger of Allah, I intend to join the expedition and I seek your advice." The Prophet said: Do you have a mother? He said yes. The Prophet said: Stay with her, for Paradise is beneath her feet. [Sunan An-Nasa'i 3104, Grade: Sahih].

Hence, our duty to our mothers is not optional or recommended. It is an obligation and Allah has forbidden us from neglecting our mothers and our parents in general. AlMughirah ibn Sha'bah reported: The Messenger of Allah, peace and blessings be upon him, said: Verily, Allah has forbidden you from neglecting your duty to your mothers. [Source: Sahih Bukhari 5630, Grade: Sahih]. In the verse of the Qur'an attach importance to the honor of the parents [father and mother], whereas in the hadith emphasize respect for a mother.

\section{Filial Piety to Parents According to Confucius}

Kungzi [Confucius], who come to be known in the West as Confucius, lived at time when the Zhou Kingdom had already collapsed [551-479 B.C.E]. [John L.McCreey in Reymmond Scupin, Editor, 2000: 279]. He symbolises oriental civilization and represents the peak of traditional Chinese thought and culture. He is, perhaps, the most famous Chinese of all and his reputation a household word. For all his fame however, the Analects [SuSi], the Confucian classic which best embodes his thinking, baffle the Chinese reader. The contents of the 20 sections [pian] of the Analects are out of order, their arrangement is unsystematic and sentences are scattered haphazardly within sections. Where it not for the arduous sorting and scrupulous interpretation of generations of commentators, where could we now find so much of its profundity of utterance and meaning? [Qian Ming: 9]. Appalled by the chaos of the world in which he found himself, Confucius traveled from one to another of the states that were struggling to replace the Zhou, attempting to persuade their rules to model themselves on the ancient sages. If, He argued, rules would display the human-heartedness called ren, Heaven would recognize their virtue, people would flock to support them, and unity and order would be restored. [John L.McCreey in Reymmond Scupin, 2000: 280].

In the Analects, a book which records discussions between Confucius and his disciples, we find that human-heartedness is displayed in many ways, such as avoiding war and excessive taxation. But by far the most important among them is sincerity in behaving according to $l i$, the proprieties exemplified by sacrificial ritual. Human-heartedness governed by $l i$ means conforming to social conventions. Subjects should be loyal, children filial, wives obedient, friends faithful, and subordinates should always defer to superiors [John L.McCreey in Reymmond Scupin, 2000: 280]. $L i$ is sometimes interpreted as a ritual to honor parents. [Tanggok, 2017: 15]. Respect for parents has been practiced by Chinese people in everyday life.

Confucius's views on respect for parents can be seen in his dialogue with his students:

Ziyou asked about Filial Piety. The Master [Confucius] said: "What is called Filial Piety today is just the keeping of parents. Dogs and horses are kept, and if there is no respect, where lies the difference? [Ming: 30]. On another occasion, Confucius also 
dialogue with his other disciples: Zixia asked about Filial Piety. The Master said: "It is not easy to always maintain a smiling countenance towards one's mother and father. Can just helping with their affairs and letting them eat first be regarded as Filial Piety? [Chang: 30]. We can say, without the qualities of love and respect, care and maintenance cannot be true Filial Piety. On another occasion Confucius dialogue again with his students: The Master said: "Serving one's parents resembles offering humble advice. When they are unwilling, maintain respect and do not disobey, feel anxiety but do not hate [Chang: 30 ].

We can say, filial piety is easy in principle but difficult in practice. We can also say, filial piety only exists in concept and is difficult to implement.

After the parents died, Confucius also ordered to honor the parents. As an example of his dialog below: The Master said: "While the father lives observe the son's aspirations; when the father is dead observe his conduct. If, after three years, he continues to follow in his father's footsteps, that is Filial Piety. [Chang: 31].

We see a similarity between the views of filial piety of the Prophet Muhammad and Confucius. Both the Prophet Muhammad's and Confucius' teachings emphasize the importance of giving respect to one's parents. For Confucius, however, respecting one's parents is not only limited to their lifetime, but when they are dead as well, such as through rituals in the home, Chinese temples and tombs.

In addition to Analects, an explanation of respect for one's parents can also be found in the book Di Zi Gui [Teaching of Ethics]. Di Zi Gui was written based on the Analects by Li Yuxiu, who lived during the Qing Dynasty and during the time that Emperor Kangxi came to power between 1661-1722 [Di Zi Gui: 8-9]. Di Zi Gui has become the basis for education on ethics in many schools in China.

The following is stated in Di Zi Gui: when one is called by one's parents, he is to quickly reply without delay; if they give one a task, one is to do it immediately and not be lazy; if one's parents give advice, it should be received with respect [Di Zi Gui]. This is the teaching of how to respect one's parents.

\section{Conclusion}

The Quran, ahādīth and the Analects all emphasize the importance of respecting one's parents. The ahāīith, however, suggest a kind of respect for one's parents in which the share for one's mother is three times greater than that for one's father. The Analects, meanwhile, conceive of a sort of respect to one's parents similar to that which is described in the Quran, namely that both parents should receive it, without stipulating any difference in how much each should receive. The Analects also state that one is to honor his parents when they are both alive and dead, whereas in the ahādīth, respecting one's parents is emphasized only when they are alive. After they die, a Muslim child's duty is just to pray for them.

In Islam, disrespecting one's parents and disobeying parental commands are considered impious and the consequence for those who commit these acts is torture in hell. In contrast, in Confucianism, especially in the teachings of Confucius, a person who does not fulfill the demands of filial piety will not go to hell. For this reason, some argue that Confucius did not teach about life after death. For this reason some people say that Confucianism is not a religion but a philosophy. Confucian followers in Indonesia, believe that Confucius teachings are not philosophy, but religion. 
In the ahādith it is said that heaven is under the feet of the mother. This means that the person who does not respect his mother will not go to heaven. This condition is not encountered in the Analects. In this context, the Analects do not speak about heaven and hell, but rather only stress that a human being must respect his parents.

\section{References}

Abu Abdillah Muhammad bin Ahmad bin Abu Bakar al-Anshari al-Qurthubi, Al-Jami' Li Ahkam Al-Quran [Beirut-Lebanon: al-Resalah Publisher [Mu'assasah al-Risalah], 2006.

Ali, Abdullah Yusuf, The Meaning of The Holy Quran, Washington, D.C., Amanah Corporation, 1991.

Fenton, John Y., and friends [Ed.], Religion of Asia, New York: St. Martins Press, 1993.

Imam Muslim [Abdul Hamid Siddiqi: Translator], Sahih Muslim, Volumes I-IV, 2000

Li Yuxiu, Di Zi Gui [Education of Ethics].

Muller, A. Charles [translater], Analects of Confucius, 1990

Mulyono, Edi. dkk., Belajar Hermeneutika [Learning Hermaneutic], Jakarta: IRCiSod, 2012.

McCreey, John L., in Reymmond Scupin, Editor, Traditional Religions of China, Upper Saddle River, N.J. : Pearson Prentice Hall, 2008.

Ming, Qian, The New Analects Confucius Reconsructed A Modern Reader, Better Link Press.

Mulyono, Edi. dkk., Belajar Hermeneutika [Learning Hermaneutic], Jakarta: IRCiSod, 2012.

Tanggok, M. Ikhsan, Jalan Keselamatan Melalui Agama Khoghucu [The Way of Salvation Through the Khoghucu Religion], Jakarta: PT. Gramedia Pustaka Utama, 2000.

Syaikh Imam Al Qurthubi, Tafsir Al Qurthubi [translation], Jakarta, Pustaka Azzam, 2016.

Tanggok, M. Ikhsan, Agama dan Kebudayaan Orang Hakka di Singkawang [Religions and Hakka Cultures in Singkawang], Jakarta: PT. Kompas-Gramedia, 2017.

Van Voorst, Rebert E., Anthology of World Scriptures Eastern Religions, USA: Holly J. Allen, 2007. 